\title{
37. ELASTIC WAVE VELOCITIES IN LAYER 2A FROM FULL WAVEFORM SONIC LOGS AT HOLE 504B ${ }^{1}$
}

\author{
Daniel Moos, David Goldberg, Michael A. Hobart, and Roger N. Anderson, \\ Lamont-Doherty Geological Observatory ${ }^{2}$
}

\begin{abstract}
During DSDP Leg 92, a full waveform, multi-channel, sonic logging tool was deployed in Hole 504B, which is located in $5.9 \mathrm{Ma}$ crust of the Costa Rica Rift. Fifty suites of eight recorded waveforms were obtained over the upper $150 \mathrm{~m}$ of oceanic Layer 2, with a source-receiver separation ranging from 2.4 to $5.5 \mathrm{~m}$. Sonic compressional wave and shear wave velocities were determined from the recorded waveforms. The results are more reliable than Schlumberger sonic logs recorded over the same interval during Leg 83 . Variations in the measured velocities are related to structural variations observed in a borehole televiewer log. Compressional and shear velocities are highest in flows (5.26 to 6.35 and 2.75 to $3.81 \mathrm{~km} / \mathrm{s}$, respectively) and are significantly lower in pillows ( 3.35 to 4.84 and 2.03 to $2.70 \mathrm{~km} / \mathrm{s}$ ). The $V_{\mathrm{p}} /$ $V_{\mathrm{s}}$ ratio varies between 1.7 and 1.9 in both pillows and flows. Compressional velocity is not affected significantly by fracturing, but shear velocity decreases, resulting in a higher $V_{\mathrm{p}} / V_{\mathrm{s}}$. Low compressional and shear velocities in the upper few hundred meters of basement are attributed to the concentration of high-porosity pillows in this interval. These results are consistent with theoretical predictions of the effects of cracks on velocities, and they indicate that it may be possible to discriminate between pillows and flows purely on the basis of sonic velocities.
\end{abstract}

\section{INTRODUCTION}

Until the advent of the Deep Sea Drilling Project, investigations of the properties of the oceanic crust relied almost exclusively on the results of seismic refraction experiments (e.g., Houtz and Ewing, 1976; Spudich and Orcutt, 1980). As seismic data collection and analysis techniques have grown more sophisticated, the details of the velocity structure of the crust have been increasingly revealed. The uppermost basement has been generally subdivided into the following oceanic layers: Layer $2 \mathrm{~A}$, with compressional velocities of 3 to $4 \mathrm{~km} / \mathrm{s}$; Layer $2 \mathrm{~B}$, with velocities of 4.8 to $5.7 \mathrm{~km} / \mathrm{s}$; and Layer $2 \mathrm{C}$, with velocities of 6.0 to $6.4 \mathrm{~km} / \mathrm{s}$. The thickness of these layers varies; in particular, the thickness of Layer $2 \mathrm{~A}$ decreases rapidly with increasing age. The resolution of seismic experiments, however, is limited by the seismic wavelength. Therefore, further determination of the details of crustal heterogeneity on scales of a few tens of meters or less cannot be made by seismic experiments alone.

Because of this limitation, detailed crustal studies have been possible only by using DSDP drill holes. Perhaps the most intensely studied of these is Hole 504B, which was drilled during a succession of DSDP legs to $1350 \mathrm{~m}$ sub-bottom depth (a sub-basement depth of $1075.5 \mathrm{~m}$ ). A full suite of geophysical logs was recorded in Hole 504B, and the results have been widely discussed (see, e.g., Cann and Von Herzen, 1983; Anderson et al., 1985; Newmark et al., 1985; Salisbury et al., 1985). The initial site surveys included detailed sonobuoy and seis-

\footnotetext{
${ }^{1}$ Leinen, M., Rea, D. K., et al., Init. Repts. DSDP, 92: Washington (U.S. Govt. Printing Office).

2 Addresses: Lamont-Doherty Geological Observatory, Columbia University, Palisades, NY 10964; (also for Goldberg) Department of Geological Sciences, Columbia University, Palisades, NY 10964.
}

mic experiments (Langseth et al., 1983; Hobart et al., 1985), and during Legs 70 and 92 oblique seismic experiments were run at the site (Stephen, 1983; Stephen and Harding, 1983; Little and Stephen, 1985).

The exact nature of the variation of compressional velocity with depth in the uppermost basement at Site 504 has been much debated. Although a zone with average sonic compressional velocities equivalent to seismic velocities in Layer $2 \mathrm{~A}$ ( 2.9 to $4.5 \mathrm{~km} / \mathrm{s}$ ) was clearly identified in Schlumberger sonic logs recorded during Leg 83 (Newmark et al., 1985; Salisbury et al., 1985), it was not seen in sonobuoy data (Langseth et al., 1983; Hobart et al., 1985) or in data from the oblique seismic experiment (Little and Stephen, 1985). Theoretical considerations suggest that this layer is too thin to be resolved by sonobuoy experiments (Mutter and Newmark, this volume) but that it should be resolvable by the oblique seismic technique. Although the crustal model generated from the oblique seismic data does show a low velocity ( 4.3 to $4.8 \mathrm{~km} / \mathrm{s}$ ) layer in the uppermost $264 \mathrm{~m}$ of basement (Little and Stephen, 1985), these velocities are considerably higher than those measured by the Schlumberger sonic log. Thus, Little and Stephen (1985) suggest that the sonic low-velocity zone is discontinuous.

To gain a better understanding of the structure of the uppermost basement at Site 504, a newly developed multi-channel sonic logging tool was deployed in Hole 504B during the latter part of Leg 92. The goals of this experiment were as follows: (1) to better determine the details of the compressional wave velocity structure of oceanic Layer $2 \mathrm{~A}$, particularly the relationship of velocity to fracturing; (2) to more accurately determine the shear wave velocity over the same interval; and (3) to study the relationship between the amplitude and frequency content of the sonic arrivals and the degree of fracturing and alteration in the pillows and flows of Layer $2 \mathrm{~A}$. 
This paper discusses the relationship between compressional wave and shear wave sonic velocities and structure determined from a borehole televiewer log in the interval from 276.5 to $426.5 \mathrm{~m}$ sub-bottom depth (the uppermost $150 \mathrm{~m}$ of basement). We rely for our structural information almost exclusively on the borehole televiewer $\log$, because core recovery in the uppermost $200 \mathrm{~m}$ of basement was only $34 \%$ (Cann et al., 1983).

\section{PREVIOUS RESULTS}

During Leg 83, a Schlumberger long-spaced sonic log was obtained throughout the basement section of Hole 504B. The Schlumberger long-spaced sonic tool consists of two sources and two receivers configured such that energy is recorded from one 8-ft, two $10-\mathrm{ft}$, and one 12$\mathrm{ft}$ source-receiver offset. Compressional wave and shear wave sonic velocities were determined at the site using a standard threshold-picking device. The results are discussed in detail by Newmark et al. (1985) and Salisbury et al. (1985). Sonic logs recorded over the upper $200 \mathrm{~m}$ of basement ( 274.5 to $474.5 \mathrm{~m}$ sub-bottom) are reproduced in Figure 1. The logs have been averaged over 3-m intervals, both to reduce the scatter in the data and to facilitate comparison with the multi-channel log. Below

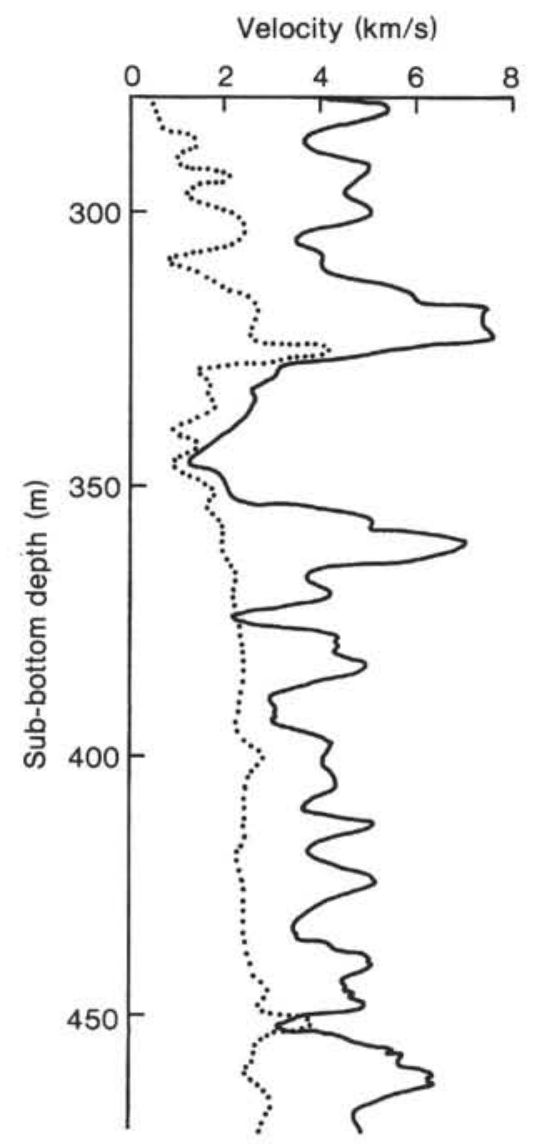

Figure 1. Compressional (solid line) and shear (dotted line) sonic wave velocities from Schlumberger logs recorded during Leg 83 in the upper $200 \mathrm{~m}$ of basement at Hole 504B. The data were averaged over 3-m intervals, both to decrease the scatter and to facilitate comparison with the multi-channel log recorded during Leg 92 . The sediment/basement interface is at $274.5 \mathrm{~m}$ sub-bottom.
$370 \mathrm{~m}$, measured compressional velocities range from 3.0 to $6.0 \mathrm{~km} / \mathrm{s}$, and measured shear velocities range from 1.8 to $2.4 \mathrm{~km} / \mathrm{s}$. In the interval from 310 to $370 \mathrm{~m}$, measured compressional velocities vary from less than $2 \mathrm{~km} / \mathrm{s}$ to greater than $7 \mathrm{~km} / \mathrm{s}$; and measured shear velocities are below $1.6 \mathrm{~km} / \mathrm{s}$ (the velocity of compressional waves in the fluid) in most of the uppermost $80 \mathrm{~m}$. These extreme values are due to cycle skipping, which is particularly severe in highly fractured or porous materials; they were not included in the above analyses.

During Leg 83 a borehole televiewer (BHTV) log was obtained from just below the sediment/basement interface at $274.5 \mathrm{~m}$ sub-bottom to the bottom of the well. These are discussed in detail by Newmark et al. (1985). Using the BHTV log, the distribution of pillows, flows, and breccias can be determined even when core recovery is poor. The structural log determined from the BHTV records is supported by analyses of the available core.

Full waveform sonic logs were also obtained throughout the basement section and were used to determine compressional and shear velocities (Anderson et al., 1985). To obtain meaningful velocity measurements using this technique the arrivals at each receiver must be highly correlatable. Therefore, this technique could only be used to analyze the data collected in the dikes of Layer $2 \mathrm{C}$. In this part of the hole, the velocities calculated from these waveforms agree with the Schlumberger sonic log. Statistical analyses of the sonic and other logs (including the BHTV log) reveal a systematic relationship between fracturing and sonic properties, such as the velocity, energy, and frequency content of compressional and shear head waves and of the borehole normal modes (Anderson et al., 1985).

Laboratory ultrasonic velocities measured in core samples from Layer $2 \mathrm{~A}$ are markedly higher than the log velocities (Salisbury et al., 1985). In Layers 2B and 2C, however, the sonic and ultrasonic velocities agree to within about $10 \%$. The differences between the sonic and ultrasonic velocities are explained by the in situ bulk porosity (Salisbury et al., 1985). Bulk porosity includes both vesicular and fracture porosity; it is as high as $15 \%$ in the uppermost several hundred meters of basement (Becker, 1985). Differences between sonic and ultrasonic velocities were previously observed in fractured rock on land (Stierman and Kovach, 1979; Moos and Zoback, 1983) and in other DSDP holes (e.g., Salisbury et al., 1980).

\section{MULTI-CHANNEL SONIC LOGGING}

Standard sonic logging tools are designed to measure compressional wave velocities either by the direct measurement of the arrival time of a refracted compressional wave, or by the difference between arrival times at a pair of receivers. Recently, velocity tools that record the full arriving waveform in the borehole have become available. The accuracy of velocities measured by these tools is limited by such factors as the number and spacing of the receivers and the bandwidth of the source.

Recent experimental designs have been developed to overcome these limitations. Reducing the distance between receivers increases the depth resolution. Increas- 
ing the number of receivers enables direct observation of the variation in energy and frequency content of the arrivals across the receiver array. The tool used in this experiment consists of a single source and a suite of 12 receivers positioned downhole from the source. The distance from the source to the nearest receiver is $2.4 \mathrm{~m}$, and the receivers are spaced $0.3 \mathrm{~m}$ apart. This contrasts with the Schlumberger tool, which has a receiver spacing of $0.6 \mathrm{~m}$. A schematic of the multi-channel tool is shown in Figure 2. In its original configuration, the receiver string was connected to the upper section by a length of standard 7-conductor logging cable. Because of this design, the receiver array was damaged during deployment of the tool at Site 597, resulting in the operational loss of receivers $4,7,8$, and 12 . The problem was corrected by placing a length of 3.5 -in. steel tubing over the logging cable connecting the source and receiver sections. With this modification, full waveforms were successfully obtained during the last part of Leg 92 in Hole 504B using the eight remaining receivers.

Both the Schlumberger tool and the multi-channel sonic tool are broadband; however, in the borehole environment the multi-channel tool had a slightly lower center frequency (about $10 \mathrm{kHz}$ compared to the $12 \mathrm{kHz}$ center frequency of the Schlumberger tool). Typically, the amplitude of the compressional arrival in Hole 504B at the first receiver was down $3 \mathrm{~dB}$ at 8 and $12 \mathrm{kHz}$. The narrow bandwidth of borehole sonic data is due largely to the filtering effect of the borehole (Paillet and White, 1981).

During operations in Hole 504B, 50 suites of waveforms were recorded every $3 \mathrm{~m}$ over the uppermost $150 \mathrm{~m}$ of basement. Source depths ranged from 279 to $426 \mathrm{~m}$ sub-bottom. This resulted in almost complete coverage of the hole through the uppermost basement section. The tool was kept at a fixed depth during the recording of each suite. Ship heave and cable stretch unavoidably cause changes in the position of the tool during the recording process and thus reduce depth accuracy. However, since the tool is rigid and source-to-receiver separation is fixed, variations in source-to-receiver traveltime are due only to changes in rock properties and borehole geometry.

An example of a suite of waveforms recorded by the multi-channel sonic tool is shown in Figure 3. Both the shear and compressional arrivals can be seen clearly. The lower amplitude of the compressional arrival is due to the nature of energy partitioning between the various borehole modes (as discussed by Cheng and Toksöz, 1981). Although compressional and shear wave moveout across the receiver array is linear, there are considerable arrivaltime variations at the individual receivers. This can be caused by small-scale velocity variations or local borehole size changes and is typical of the entire depth interval studied.

\section{RESULTS}

Average compressional wave velocities across the receiver array were determined for each source point using a threshold-picking scheme. The results were verified manually. Shear arrivals were picked manually, because the

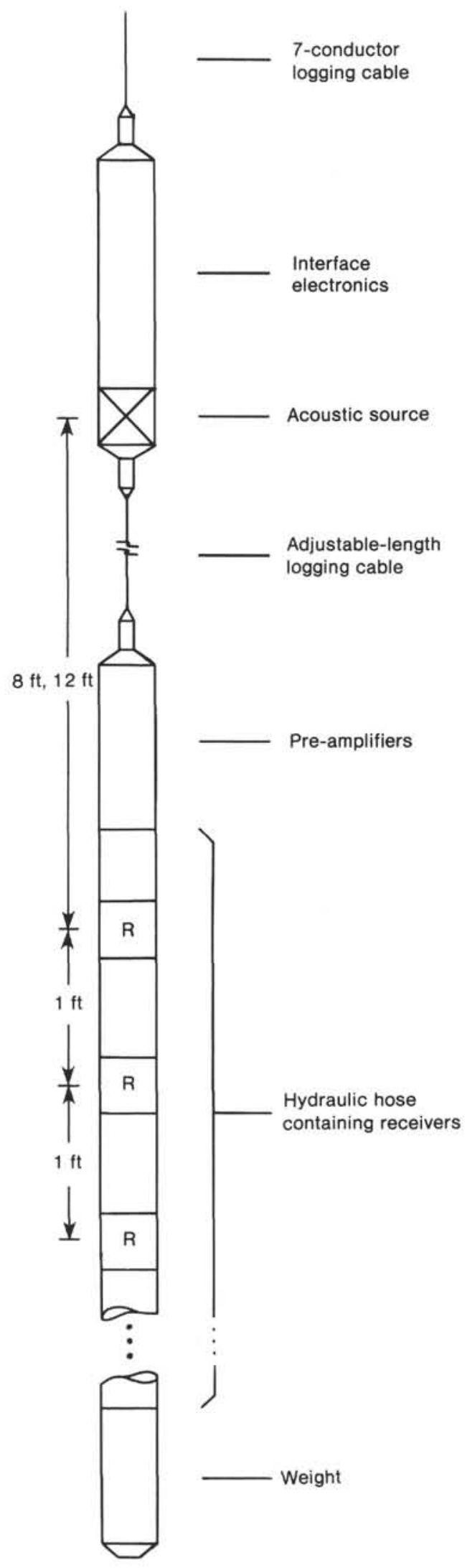

Figure 2. Schematic drawing showing the original configuration of the logging tool. After preliminary experiments at Site 597, a section of 3.5 -in. steel tubing was run over the cable connecting the source and receiver sections to improve the rigidity of the tool. $\mathrm{R}=$ receiver. 


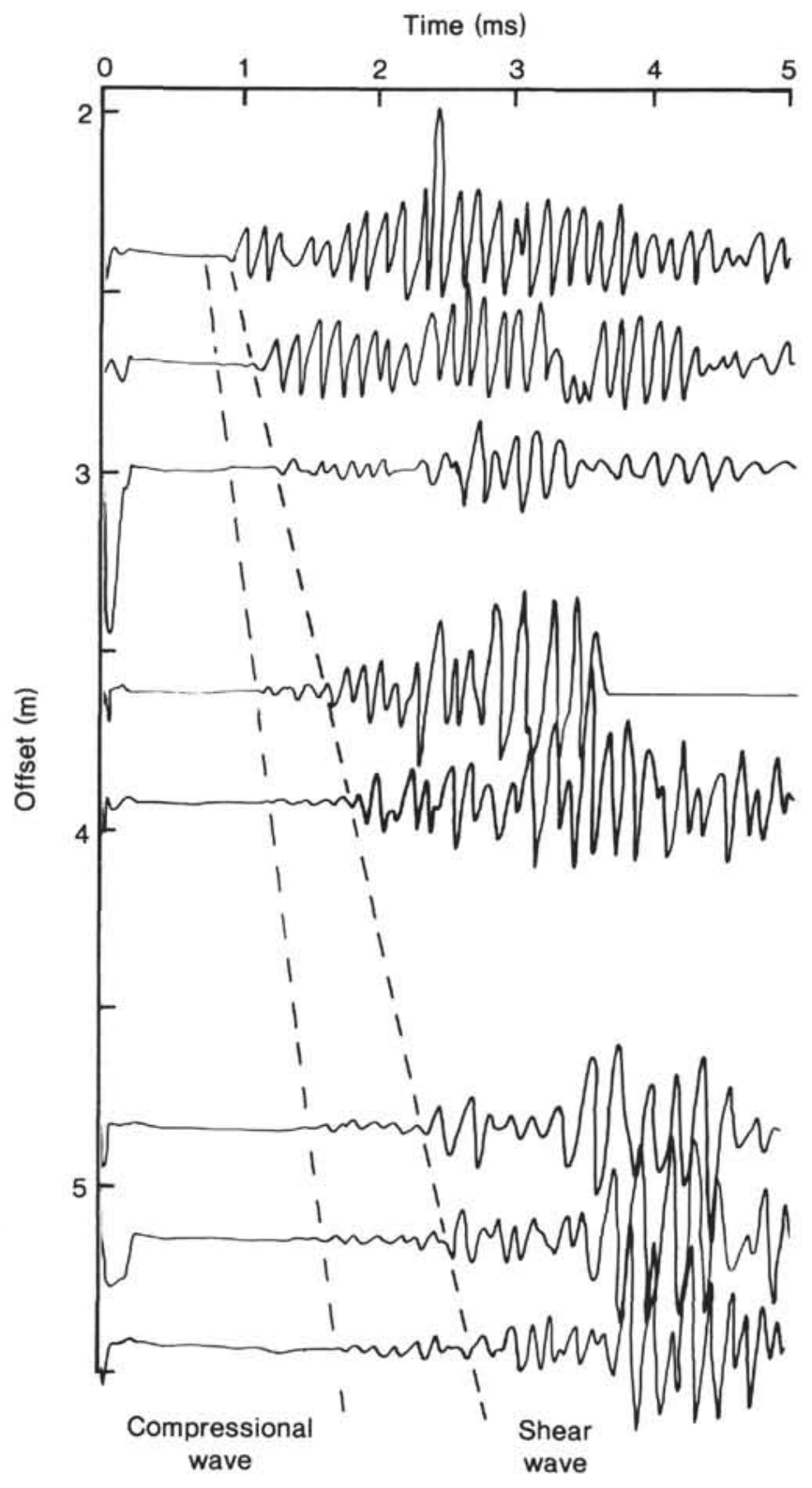

Figure 3. An example of the full waveforms recorded by the sonic tool. The average moveout across the receiver array for both compressional and shear head waves is indicated by the dashed lines. These waveforms were recorded with the source at a depth of $301.5 \mathrm{~m}$ sub-bottom.

threshold scheme did not provide sufficiently reliable results. Attempts to use a modified semblance scheme (e.g., Kimball and Marzetta, 1984; Goldberg, Gant, et al., 1984) were unsuccessful, mainly because of spatial aliasing of longer wavelength energy across the receiver array. Also, variations in moveout between the receivers decreases the reliability of the semblance technique. Velocity variations within the array were not determined, because tool eccentering results in splitting and possible misinterpretation of the arrivals (Roever et al., 1974; Goldberg, Kan, et al., 1984) and the tool was not reliably centralized.

The results of the velocity calculations are shown in Figure 4. Also shown is the velocity ratio and a structural section derived from the BHTV log (discussed below).
Comparison of the logs recorded by the Schlumberger sonic tool and by the multi-channel sonic tool is limited to intervals where both tools were giving reasonable results. In these intervals velocities measured by the multi-channel tool were approximately equal to or slightly greater than those measured by the Schlumberger tool. The multi-channel tool, however, was more reliable, consistently yielding results throughout the interval. Also, details of the variations in shear velocity were revealed by the multi-channel tool that were not seen in the Schlumberger log. As a result, $V_{\mathrm{p}} / V_{\mathrm{s}}$ calculated from the full waveform data more accurately represents the in situ properties.

Compressional wave velocities measured from the multi-channel sonic waveforms range from about 3.3 to $6.5 \mathrm{~km} / \mathrm{s}$. Significant low-velocity zones occur in the intervals from 310 to $320 \mathrm{~m}$, from 335 to $355 \mathrm{~m}$, and from 380 to $400 \mathrm{~m}$ in both logs. Thinner low-velocity zones occur throughout the interval. In the interval from 310 to $370 \mathrm{~m}$, where the Schlumberger log compressional velocities ranged from $<2$ to $>7 \mathrm{~km} / \mathrm{s}$, the multi-channel results are more reasonable.

Shear wave velocities measured from the multi-channel waveforms range from 2.0 to $3.8 \mathrm{~km} / \mathrm{s}$. Low-velocity zones occur in the intervals from 290 to $315 \mathrm{~m}$, from 335 to $355 \mathrm{~m}$, and from 370 to $400 \mathrm{~m}$; they coincide roughly with the intervals of low compressional velocity (mentioned above). $V_{\mathrm{p}} / V_{\mathrm{s}}$ varies between 1.7 and 2.2 over the logged interval, but no unique relationship is apparent between $V_{\mathrm{p}} / V_{\mathrm{s}}$ and either $V_{\mathrm{p}}$ or $V_{\mathrm{s}}$.

These variations in velocity are not surprising, in view of the structural complexity within this interval. The BHTV log indicates that the uppermost $30 \mathrm{~m}$ represent a relatively thick basalt flow that is highly fractured at the top and has a narrow zone of large pillows near its base. Velocities in this interval seem to depend on the degree of fracturing and are lowest in the pillow basalts. The underlying 15 -m-thick pillow basalt has low shear and compressional velocities and a low $V_{\mathrm{p}} / V_{\mathrm{s}}$ ratio. Below the pillow basalt is a 10 -m-thick massive flow that is fractured at its base. Shear and compressional velocities increase sharply in this interval. The underlying $40 \mathrm{~m}$ are mostly pillow basalts, with one thin high-velocity flow at $340 \mathrm{~m}$ sub-bottom. Below that is a fractured flow characterized by a relatively high compressional velocity, and a high $V_{\mathrm{p}} / V_{\mathrm{s}}$ ratio that grades into a zone of intermixed fractured pillows and flows. As the number of pillows increases with depth, $V_{\mathrm{p}}, V_{\mathrm{s}}$, and $V_{\mathrm{p}} / V_{\mathrm{s}}$ all decrease. The lowermost $20 \mathrm{~m}$ represent a thick, high-velocity flow. A thin zone of low-velocity pillows occurs within the flow at about $415 \mathrm{~m}$. These observations suggest that there is a relationship between velocity and lithologic structure, possibly controlled by porosity and pore aspect ratio, which will be discussed in more detail in the next section.

\section{DISCUSSION}

The relationship between sonic wave velocities and pore aspect ratio has been widely discussed. A number of theoretical models have been developed that suggest that velocity is inversely proportional to crack density and that the ratio of compressional to shear velocity is in- 

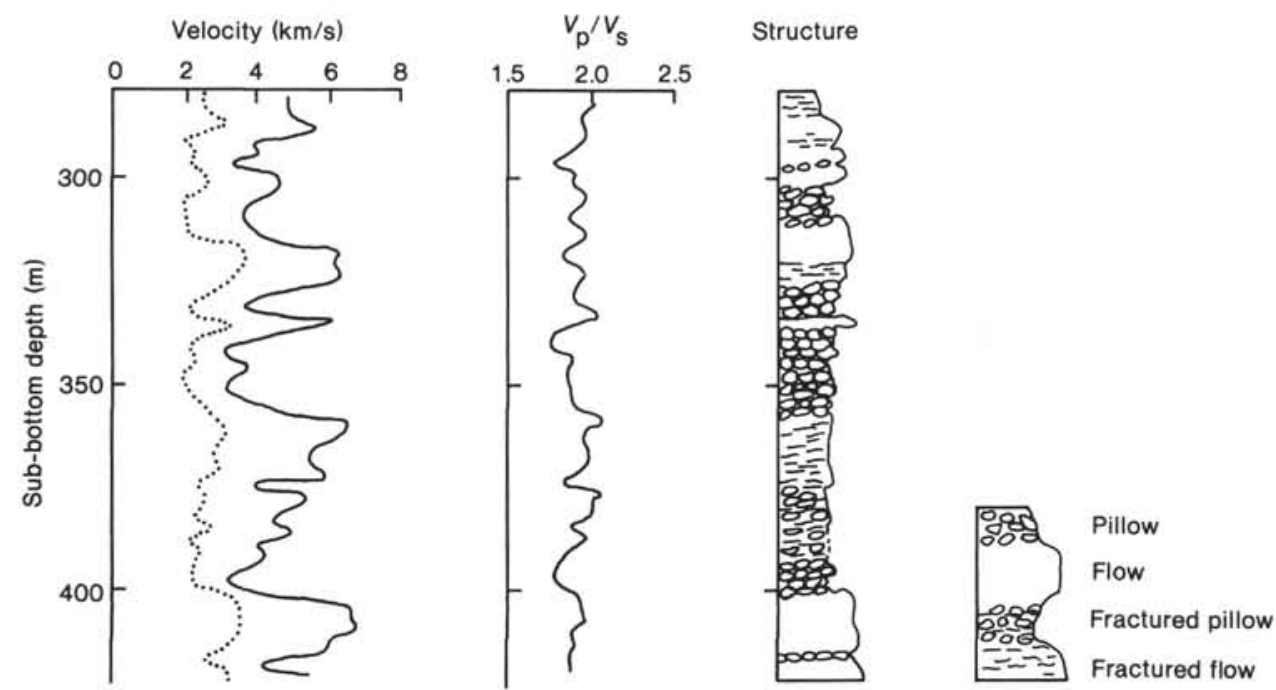

Figure 4. Compressional (solid line) and shear (dotted line) logs calculated from the full waveform recordings in the upper $150 \mathrm{~m}$ of basement. The sediment/basement interface is at $274.5 \mathrm{~m}$ sub-bottom. $V_{\mathrm{p}} /$ $V_{\mathrm{s}}$ calculated from the sonic logs is also shown. On the right is a structural log determined from BHTV records obtained during Leg 83 .

versely proportional to crack aspect ratio (O'Connell and Budianski, 1974; Toksöz et al., 1976). Therefore, the velocities and their ratio should be related both to crack density and to crack aspect ratio. Unfortunately, field results are not quite as straightforward. Moos and Zoback (1983) observed that sonic velocities in granitic rocks decrease with increasing fracture density, whereas $V_{\mathrm{p}} / V_{\mathrm{s}}$ increases. They attribute these results to the combined effects of the fractures and related alteration. However, Goldberg, Gant, et al. (1984) have observed that sonic velocities decrease in vertically fractured limestones, although $V_{\mathrm{p}} / V_{s}$ remains unaffected.

Independent estimates of porosity can be obtained by a variety of techniques. Direct measurements in the laboratory yield estimates of the pore and microcrack porosity of the recovered samples; interpretations of Schlumberger neutron logs provide estimates of the in situ porosity in the vicinity of the borehole; and large-scale resistivity measurements can be used to calculate the porosity of the rock volume away from the borehole. The in situ measurements often differ from the laboratory measurements because of the presence of fractures and voids not sampled by the core. The porosity of the recovered core in the uppermost $200 \mathrm{~m}$ of basement varies between 2.69 and $11.52 \%$, although most of the values are between 4 and $8 \%$, with a mean of $5.3 \%$ (Cann et al., 1983). Bulk porosity over the same interval calculated from the neutron log is approximately $15 \%$ (Anderson et al., 1985). Porosity calculated from the largescale resistivity experiment is 10 to $14 \%$ (Becker, 1985). Becker (1985) suggests that well logs may yield slightly higher estimates of porosity because of the localized effects of drilling. However, the discrepancy between the laboratory data and both sets of field results is quite pronounced. Either the recovered samples have anomalously low porosities, or additional in situ porosity is present in the form of open fractures and voids.
To study the relationship between sonic velocities and the distribution of pillows and flows in the uppermost $150 \mathrm{~m}$ of Hole 504B, a structural interpretation of the BHTV log was compared with the measured velocities. Four subunits were chosen to represent the structural complexity in the logged interval. These are (1) flows, (2) pillows, (3) fractured flows or breccia zones, and (4) intermixed fractured pillows and flows. The average velocities within each of these units were then calculated from the multi-channel sonic waveforms. Theoretically, variations in $V_{\mathrm{s}}, V_{\mathrm{p}}$, and $V_{\mathrm{p}} / V_{\mathrm{s}}$ between these units should be indicative of variations in the aspect ratios of microand macroscopic components of the porosity. If the velocities and their ratio do vary systematically, those variations would allow discrimination between the different structural units on the basis of the sonic logs alone.

Table 1 presents the results of these calculations. First, the flows have the highest measured velocities. Velocities in the pillows are much lower, and those in intermixed fractures and pillows are intermediate. The $V_{\mathrm{p}} / V_{\mathrm{s}}$ ratio is about the same within the pillows and flows. Second, compressional wave velocity does not decrease significantly in the fractured intervals. However, $V_{\mathrm{p}} / V_{\mathrm{s}}$ is higher because of the lower shear velocities. This relationship is observed in both flows and pillow basalts. The same relationships are presented graphically in Figure 5. Note again that fracturing in the flows reduces the shear velocity, which in turn increases the velocity ratio; in pil-

Table 1. Comparison of lithology and sonic velocities.

\begin{tabular}{lccc}
\hline \multicolumn{1}{c}{ Rock type } & $V_{\mathrm{p}}(\mathrm{km} / \mathrm{s})$ & $V_{\mathrm{s}}(\mathrm{km} / \mathrm{s})$ & $V_{\mathrm{p}} / V_{\mathrm{s}}$ \\
\hline Flow & $5.26-6.35$ & $2.75-3.81$ & $1.71-1.86$ \\
Fractured flow & $5.85-6.35$ & $2.90-3.35$ & $1.84-2.08$ \\
Pillows & $3.35-4.84$ & $2.03-2.70$ & $1.63-1.81$ \\
Fractured pillows and flows & $3.91-5.75$ & $2.21-2.90$ & $1.87-1.91$ \\
\hline
\end{tabular}




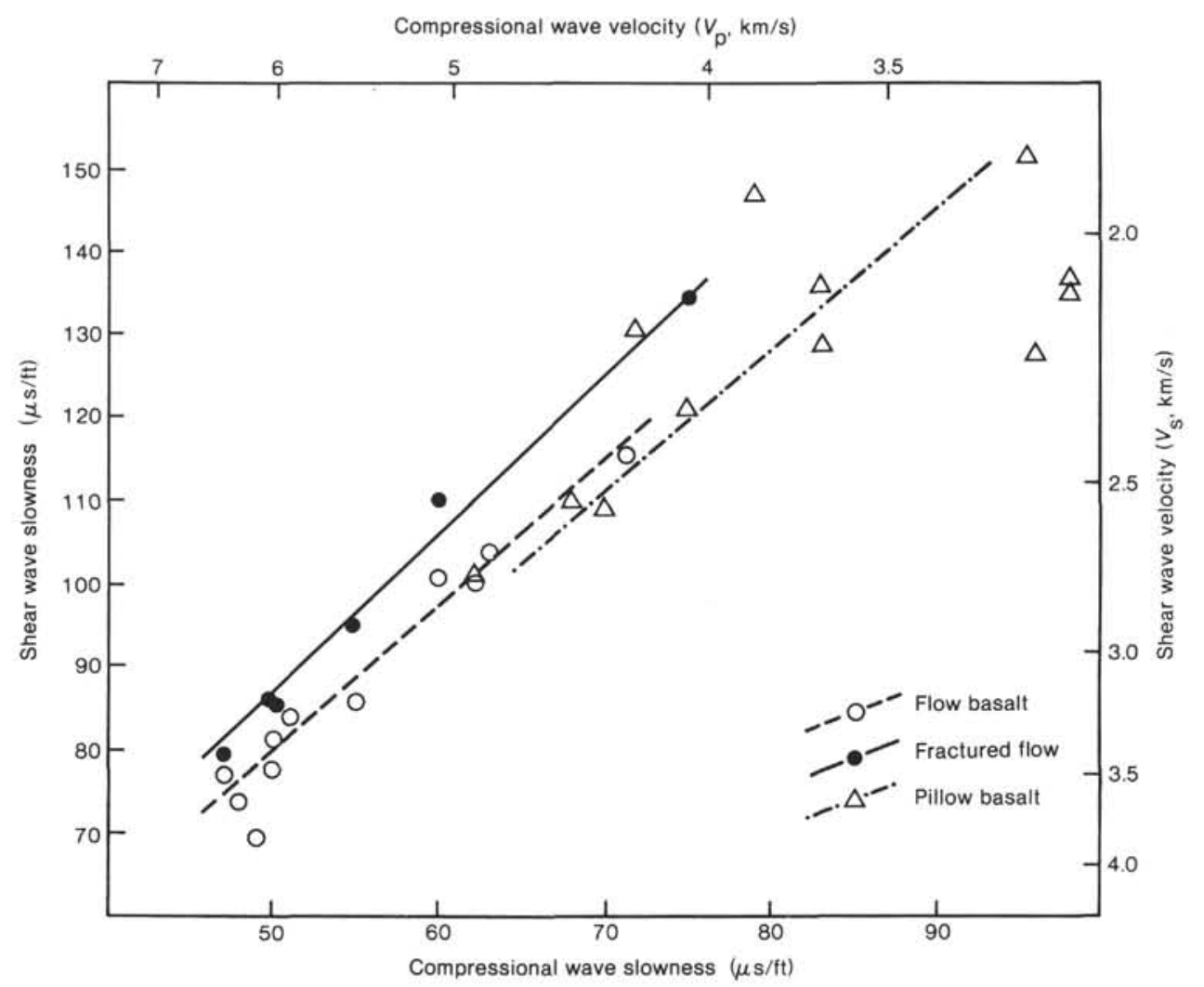

Figure 5. Crossplot of $V_{\mathrm{p}}$ and $V_{\mathrm{s}}$ for sonic velocities calculated from the full waveform data. The data are summarized in Table 1 . The lines show the average $V_{\mathrm{p}} / V_{\mathrm{s}}$ ratio for the plotted data. Data from intervals of mixed fractured pillows and flows were not included so as to avoid obscuring the relationship between structure and elastic properties.

lows both compressional and shear velocities are lower. (Points corresponding to zones of mixed fractured pillows and flows are not shown.)

The in situ sonic wave velocities are consistent with laboratory ultrasonic velocities measured in core samples. Samples recovered during drilling all have ultrasonic compressional velocities between 5.7 and $6.4 \mathrm{~km} / \mathrm{s}$ and shear velocities between 3.1 and $3.4 \mathrm{~km} / \mathrm{s}$ (Salisbury et al., 1985). Velocities within the unfractured flows measured from the multi-channel sonic waveforms are similar. No laboratory measurements have been obtained in pillows from this interval, because core recovery within these zones was low. However, measurements of compressional velocities have been made in cores cut from dredge samples recovered from escarpments in the North Atlantic. Ultrasonic compressional velocities in the altered samples were higher than the sonic compressional velocities in the pillows in Hole 504B, ranging from 4.0 to $4.8 \mathrm{~km} / \mathrm{s}$ (Fox et al., 1973). The velocities were inversely proportional to the degree of alteration.

Shipboard analyses of the cores from Hole 504B indicate that alteration is most extensive in the pillows, where saponite replaces olivine phenocrysts (Honnorez et al., 1983). Varying degrees of additional alteration and clay infilling are also present. Alteration in the flows is concentrated mainly along mineralized fractures, although some degree of olivine replacement also occurs. Thus, alteration in the basalts from Hole 504B is less extensive than that in the dredge samples from the North Atlan- tic. Anderson et al. (1985) calculated the degree of alteration in the basalts of Hole 504B from the neutron and density logs by assuming that the alteration is proportional to the amount of bound water within the formation. This method predicts that alteration within the uppermost $650 \mathrm{~m}$ of basement is quite variable. Alteration in the uppermost $150 \mathrm{~m}$ is not significantly higher than in the next lower $500 \mathrm{~m}$. Although there is less alteration in the pillow basalts in Hole 504B, sonic velocities are lower than the ultrasonic velocities in the cores from the North Atlantic. Therefore, the low velocities measured in the pillows in Hole 504B cannot be explained solely by an increase in alteration.

Variations in velocity in the uppermost $150 \mathrm{~m}$ of Hole 504B result from variations in the amount and character of the bulk porosity. Furthermore, those variations are related to variations in the lithologic structure. The highvelocity flows are essentially unfractured. Porosity within the pillows is mostly equidimensional, resulting in a reduction in both compressional and shear velocities. Where fractures are present, shear velocity decreases and compressional velocity is relatively unaffected, resulting in an increase in $V_{\mathrm{p}} / V_{\mathrm{s}}$.

The relationship between velocities and structure may have profound implications for the interpretation of seismic layering in the uppermost basement. Zones of low compressional velocity correlate with the presence of pillows and are not related to variations in horizontal fracture density. Thus, we confirm the conclusion of New- 
mark et al. (1985) that low velocities in this uppermost interval are due largely to the high concentration of pillow basalts. These results also extend the conclusions of Salisbury et al. (1985) that velocity and porosity are inversely related. The aspect ratio of the in situ bulk porosity is critical in determining its effect on the velocities. Low aspect ratio fractures decrease $V_{\mathrm{s}}$ and increase $V_{\mathrm{p}} / V_{\mathrm{s}}$, whereas equidimensional voids reduce both $V_{\mathrm{p}}$ and $V_{\mathrm{s}}$ without changing their ratio. Furthermore, since shear velocity is strongly affected by fracturing, $V_{\mathrm{p}} / V_{\mathrm{s}}$ in lowvelocity zones may be an additional tool to help discriminate between fracturing and the vesicular porosity in pillow basalts.

The improved compressional and shear velocities determined from the multi-channel waveforms are in much better agreement with the oblique seismic results than the earlier Schlumberger logs. Schlumberger sonic velocities were as low as $2.9 \mathrm{~km} / \mathrm{s}$ in the uppermost $200 \mathrm{~m}$ of basement (Newmark et al., 1985; Salisbury et al., 1985). Synthetic seismic profiles generated using these low values yielded incorrect shear amplitudes (Little and Stephen, 1985). Hence, Little and Stephen (1985) concluded that the low velocities seen in the log are not representative of the crustal structure at Site 504. However, the oblique seismic results are consistent with the sonic velocities presented here. Discrepancies between the sonic and seismic velocities can now be resolved without presuming the existence of a laterally discontinuous low-velocity zone.

\section{CONCLUSIONS}

The uppermost $150 \mathrm{~m}$ of basement in Hole 504B are composed of interlayered pillows and flows cut by intermittent zones of subhorizontal fractures. Because of the complexity of this interval of the well, a standard sonic log obtained during Leg 83 failed to provide reliable velocity data. The multi-channel sonic log recorded during Leg 92 improved the results. In intervals of wellcemented pillows and unfractured flows, the measured velocities from the two logs are similar, although slightly higher velocities are measured from the multi-channel $\log$. Although there was a discrepancy between the results of the earlier Schlumberger log and the oblique seismic experiments, velocities from the multi-channel sonic data are consistent with oblique seismic data and synthetics (R. Stephen, pers. comm., 1984).

Comparison of a structural log derived from the BHTV data with the multi-channel sonic log revealed that (1) competent flows had the highest velocities; (2) low compressional and shear velocities were confined mostly to zones containing pillow basalts; and (3) fracturing did not significantly affect compressional velocity, but rather caused decreased shear velocities and an increased $V_{\mathrm{p}}$ / $V_{\mathrm{s}}$ ratio. These results support the conclusions of Salisbury et al. (1985) that compressional velocities in the oceanic crust are controlled largely by porosity. In addition, they reveal that variations in shear velocity are controlled also by the crack aspect ratio. Thus, elastic wave velocities and their ratio may provide a diagnostic tool that allows fracturing in flows to be distinguished from the presence of pillows in the uppermost basement.

\section{ACKNOWLEDGMENTS}

We would like to thank the captain and crew of the Glomar Challenger and the Leg 92 DSDP staff scientists and technical support personnel. Margaret Leinen and Dave Rea were particularly supportive during the initial testing of the tool at Site 597. We would also like to thank Keir Becker and the anonymous reviewers, whose critical comments greatly improved this manuscript. Robin L. Newmark assisted us with structural determinations from the BHTV log. This work was supported by the Office of Naval Research under contracts N0001480-C-0098 and N00014-84-C-0132. Lamont-Doherty Geological Observatory contribution number 3863 .

\section{REFERENCES}

Anderson, R. N., O'Malley, H., and Newmark, R. L., 1985. Use of geophysical logs for quantitative determination of fracturing, alteration, and lithostratigraphy in the upper oceanic crust, Deep Sea Drilling Project, Holes 504B and 556. In Anderson, R. N., Honnorez, J., Becker, K., et al., Init. Repts. DSDP, 83: Washington (U.S. Govt. Printing Office), 443-478.

Becker, K., 1985. Large-scale electrical resistivity and bulk porosity of the oceanic crust, Deep Sea Drilling Project Hole 504B, Costa Rica Rift. In Anderson, R. N., Honnorez, J., Becker, K., et al., Init. Repts. DSDP, 83: Washington (U.S. Govt. Printing Office), 419427.

Cann, J. R., Langseth, M. G., Honnorez, J., Von Herzen, R. P., White, S. M., et al., 1983. Init. Repts. DSDP, 69: Washington (U.S. Govt. Printing Office).

Cann, J. R., and Von Herzen, R. P., 1983. Downhole logging at Deep Sea Drilling Project Sites 501, 504, and 505, near the Costa Rica Rift. In Cann, J. R., Langseth, M. G., Honnorez, J., Von Herzen, R. P., White, S. M., et al., Init. Repts. DSDP, 69: Washington (U.S. Govt. Printing Office), 281-299.

Cheng, C. H., and Toksöz, M. N., 1981. Elastic wave propagation in a fluid-filled borehole and synthetic acoustic logs. Geophysics, 46: 1042-1053.

Fox, P. J., Schreiber, E., and Peterson, J. J., 1973. The geology of the oceanic crust: compressional wave velocities of oceanic rocks. $J$. Geophys. Res., 78:5155-5172.

Goldberg, D. S., Gant, W. T., Seigfried, R. W., and Castagna, J. P., 1984. Processing and interpretation of sonic log waveforms: a case study. Trans. Soc. Expl. Geophys. Annu. Symp. 1984, pp. 28-31.

Goldberg, D. S., Kan, T. K., and Castagna, J. P., 1984. Attenuation measurements from sonic log waveforms. Trans. SPWLA 25th Annu. Logging Symp. 1978, Paper NN.

Hobart, M. A., Langseth, M. G., and Anderson, R. N., 1985. A geothermal and geophysical survey on the south flank of the Costa Rica Rift: Sites 504 and 505. In Anderson, R. N., Honnorez, J., Becker, K., et al., Init. Repts. DSDP, 83: Washington (U.S. Govt. Printing Office), 379-404.

Honnorez, J., Laverne, C., Hubberten, H.-W., Emmermann, R., and Muehlenbachs, K., 1983. Alteration processes in Layer 2 basalts from Deep Sea Drilling Project Hole 504B, Costa Rica Rift. In Cann, J. R., Langseth, M. G., Honnorez, J., Von Herzen, R. P., White, S. M., et al., Init. Repts. DSDP, 69: Washington (U.S. Govt. Printing Office), 509-546.

Houtz, R., and Ewing, J., 1976. Upper crustal structure as a function of plate age. J. Geophys. Res., 71:2490-2498.

Kimball, C. V., and Marzetta, T. L., 1984. Semblance processing of borehole acoustic array data. Geophysics, 49:274-281.

Langseth, M. G., Cann, J. R., Natland, J. H., and Hobart, M., 1983. Geothermal phenomena at the Costa Rica Rift: background and objectives for drilling at Deep Sea Drilling Project Sites 501, 504, and 505. In Cann, J. R., Langseth, M. G., Honnorez, J., Von Herzen, R. P., White, S. M., et al., Init. Repts. DSDP, 69: Washington (U.S. Govt. Printing Office), 5-29.

Little, S. A., and Stephen, R. A., 1985. Costa Rica Rift borehole seismic experiment, Deep Sea Drilling Project Hole 504B, Leg 92. In Anderson, R. N., Honnorez, J., Becker, K., et al., Init. Repts. DSDP, 83: Washington (U.S. Govt. Printing Office), 517-528.

Moos, D., and Zoback, M. D., 1983. In situ studies of velocity in fractured cystalline rocks. J. Geophys. Res., 88:2345-2358.

Newmark, R. L., Anderson, R. N., Moos, D., and Zoback, M. D., 1985. Sonic and ultrasonic logging of Hole 504B and its implications for the structure, porosity, and stress regime of the upper $1 \mathrm{~km}$ 
of the oceanic crust. In Anderson, R. N., Honnorez, J., Becker, K., et al., Init. Repts. DSDP, 83: Washington (U.S. Govt. Printing Office), 479-510.

O'Connell, R. J., and Budianski, B., 1974. Seismic velocities in dry and saturated cracked solids. J. Geophys. Res., 79:5412-5426.

Paillet, F. L., and White, J. E., 1981. Acoustic modes of propagation in the borehole and their relationship to rock properties. Geophysics, 47:1215-1228.

Roever, W. L., Rosenbaum, J. H., and Vining, T. F., 1974. Acoustic waves from an impulsive source in a fluid filled borehole. J. Acoust. Soc. Am., 55:1144-1157.

Salisbury, M. H., Christensen, N. I., Becker, K., and Moos, D., 1985. The velocity structure of Layer 2 at Deep Sea Drilling Project Site 504 from logging and laboratory experiments. In Anderson, R. N., Honnorez, J., Becker, K., et al., Init. Repts. DSDP, 83: Washington (U.S. Govt. Printing Office), 529-539.

Salisbury, M. H., Donnelly, T. W., and Francheteau, J., 1980. Geophysical logging in Deep Sea Drilling Project Hole 417D. In Donnelly, T., Francheteau, J., Bryan, W., Robinson, P., Flower, M.,
Salisbury, M., et al., Init. Repts. DSDP, 51, 52, 53, Pt. 1: Washington (U.S. Govt. Printing Office), 705-713.

Spudich, P., and Orcutt, J. A., 1980. A new look at the seismic velocity structure of the oceanic crust. Rev. Geophys. Space Phys., 18: 627-645.

Stephen, R. A., 1983. The oblique seismic experiment on Deep Sea Drilling Project Leg 70. In Cann, J. R., Langseth, M. G., Honnorez, J., Von Herzen, R. P., White, S. M., et al., Init. Repts. DSDP, 69: Washington (U.S. Govt. Printing Office), 301-308.

Stephen, R. A., and Harding, A. J., 1983. Travel time analysis of borehole seismic data. J. Geophys. Res., 88:8289-8298.

Stierman, D. J., and Kovach, R. L., 1979. An in situ velocity study: the Stone Canyon well. J. Geophys. Res., 84:672-678.

Toksöz, N., Cheng, C. H., and Timur, A., 1976. Velocities of seismic waves in porous rocks. Geophysics, 41:621-645.

Date of Initial Receipt: 25 July 1984

Date of Acceptance: 31 December 1984 